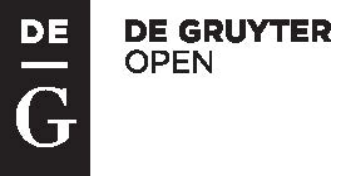

LINGUACULTURE 1, 2015

\title{
SELF-TRANSLATION, LITERARY CREATIVITY, AND TRANS-LINGUAL AESTHETICS: A QUÉBEC WRITER'S PERSPECTIVE
}

\author{
DA N I EL GA G NON
}

McGill University, Montréal

\begin{abstract}
Self-translation and bilingual writing are drawing increasing critical attention in literary and translation studies. Bilingual writing can cover a wide range of phenomena involving varying degrees of bilingualism. Scholarly focus has been on emigrant, expatriate or exiled writers and more recently, on bilingual writers writing in a postcolonial context, using the acquired language of the colonizer. The emphasis has been on the cultural and political power inequalities between languages. Self-translation has also been seen from the broader, ontological point of view as a form of double representation of the writing self. My own experience in the particular cultural geography of a binational, multicultural country such as Canada offers a different context for reflecting on self-translation and bilingual writing, or what I prefer to call "cross-writing," based on the fundamental cross-cultural communicative aesthetics underlying my specific writing and self-translation process.
\end{abstract}

Keywords: self-translation, bilingual writing, cross-writing, communicative aesthetics

Self-translation, associated with what is often called bilingual writing or the bilingual text, is drawing increasing critical attention in literary and translation studies (Oustinoff; Hokenson and Munson). The term bilingual writing is loosely applied, and covers such fluently bilingual and bicultural writers as Samuel Beckett and Julian/Julien Green, as well as those, like the Russian Nabokov, writing in English, or the Romanian Cioran writing in French, who struggled, at least initially, with the syntax of a language they were far from mastering. The notion suggests that the author is able to switch languages because of his or her bilingualism (whatever the extent) and that the presence of the author's first language necessarily informs, at some level, the text written in his or her other language. Scholarly focus has been on emigrant, expatriate or exiled writers and, more recently, on bilingual writers writing in a post-colonial context, using the acquired language of the colonizer. In this latter context, the emphasis has been on the cultural and political power inequalities between languages (Munday 133- 
134); in the former, on "dissimilarities between the two versions" in content and style (Hokenson and Munson 4). Self-translation has also been seen from the broader, ontological point of view as a form of double representation of the writing self, and studies of particular bilingual authors, in post-colonial or emigrant contexts, have explored the process as a problematic site of identity construction (Wilson 186; Nikolaou and Kyritisi; De Paula).

My own experience in the particular cultural geography of a bi-national, multicultural country such as Canada offers a different context for reflecting on self-translation and bilingual writing, or what I prefer to call "cross-writing," based on the fundamental cross-cultural communicative aesthetics underlying my specific writing and self-translation process. In the 1980s, although my first language is French, I wrote two novels directly in English: The Marriageable Daughter (Coach House Press, 1989) and My Husband the Doctor (1984, unpublished). I subsequently translated both novels into French: La fille à marier (Leméac, 1985) for which I won the Prix Molson de l'Académie des lettres du Québec, and Mon mari le docteur (Leméac, 1986). My principal motivation at the time for writing in English, although I was far from bilingual, was to escape the intense sense of confinement I felt in the French language (Gagnon, "Les mots" 47). As a Québécois francophone writing in the 1970s, I was caught between the limitations of 'joual,' a spoken form of heavily anglicized Québécois French, or the alienating straight jacket of imperial, Parisian French. Switching into English was a creative safety valve, an opportunity to find new linguistic and literary freedom.

Viewed from a post-colonial perspective, this choice, as the language of liberation, of English, the majority language in Canada, the language against whose insidious influence I had myself struggled daily as Director of the Bureau regional de diffusion du français in Sherbrooke from 1970 to 1976, could appear paradoxical. However, I had been educated in a Québec collège classique. Learning to translate from Greek and Latin had given me a profound connection with classical literature, opened my curiosity to the deep traditions rooted in these ancient civilizations that would spawn so many international literatures. To then write in 'joual,' for a small speech community, in the name of what I saw as a certain opportunistic populism, appeared to me to be a retreat into a more limited world. If international French, and especially the aesthetic norms of the French literary establishment, excluded me as a Québécois, English, although I did not master it, appeared as an accessible, alternative world language.

\section{Cross-writing and the Communicative Aesthetics}

While the desire to escape from confinement and to reach out to a broad reading public can also be associated with self-translation in emigrant or post-colonial contexts, what distinguishes my experience and underscores its specific dimension of cross-cultural writing, is the particular communicative context in 
which the experience took shape. In the late 1970s and early 1980s, I had an opportunity, on two occasions, to participate in a predominantly Anglophone writers' retreat organized by the Writers' Union of Canada at Tamwood Lodge in the Muskoka region of Ontario. Among the writers I became friends with were Helen Pereira and Helen Porter. I felt a sense of solidarity with these women writers struggling, as I was, with many of the same issues of finding a voice and an audience in an unwelcoming culture. Helen Porter considered that we were both 'outsiders' in Canada, she as a Newfoundland writer, and I as a Québécois. On our return to Toronto, fate would have it that the train conductor at Bracebridge, taking the three of us for relatives, offered us a less expensive 'family' rate. This set the playful tone for our future correspondence. I would write to Helen Pereira using the affectionate term of address, 'big sister.' Helen Pereira introduced me, by letter, to the Canadian West Coast poet Phyllis Webb, with whom I also corresponded, but whom I would only meet much later after The Marriageable Daughter was already in press at Coach House Press.

Since my written English was quite rough, and I knew my three correspondents were writers, I would open randomly the Harrap's Bilingual Dictionary for inspiration, and thus began an epistolary form of writing in English, with a lighthearted, creative bent, to 'sisters' in writing. Through these writers I was both literally and literarily in touch with the pan-Canadian reality, a vast space I had already visited and which, despite the political and linguistic differences, formed part of our shared geography and cosmology. The epistolary form of The Marriageable Daughter grew quite naturally out of this correspondence. I imagined a young Francophone girl, Jeanne Després, in Sherbrooke, writing to an imaginary pen pal, Phyllis Dalton, in Medicine Hat, Alberta. Perhaps the French-Canadian explorer tradition of the Western Plains underlay my decision to situate Phyllis in Alberta (but on the Québec side of the Rocky Mountains not on the other side where the real Phyllis Webb lived), rather than East of Québec in the Maritimes.

What is significant here for the fundamental cross-cultural dimension of my trans-lingual aesthetics is that the writing process was set in motion by a real, creative, epistolary exchange, and based on communication with a person of the other Canadian official language and culture with whom a real solidarity was possible. This communicative intention underscores the construction of the entire text from the epistolary form (the novel is composed structurally as a series of letters from Jeanne to Phyllis) to the themes of solitude, suffering and revolt, the search for meaning, shared experience and understanding. As the recipient of Jeanne's letters, Phyllis' textual presence, although she does not reply, is the principal generator of the text matter. The first paragraph sets the tone: 
Dear Phyllis,

I asked my humpbacked professeur d'anglais in Sherbrooke au Québec to give me the names ofyoung girls like me living in Canada from time immemorial, analogous to me, do me the favor of telling me, I said, the name of the young girl to whom I will write as my sister, O Phyllis, you are my dear sister in Medicine Hat, Alberta, Canada, aren't you? Do you understand me well, Excuse my so bad English, mister Smith mon professeur d'anglais gave me your precious name, if it will cure your pernicious anemia, he said, and now I have my kindred soul, I am twelve and I believe it is immoral for a woman not to give herself completely to a man she loves unless she has had the poor judgment to fall in love with a man who is bad for her, then she should run a mile from him, do you, Phyllis, on the quiet, secretly read the blacklisted books in the library room of your parents, at night with a flashlight, in your pyjamas, to have the shivers, to make you shudder, to be thrilled with delight, to have a tickle in your organism? (The Marriageable Daughter 9)

In this albeit one-sided, communicative process, linguistic difference is essential. Phyllis is at once Jeanne's personal sounding board, a kindred soul, an intimate alter ego with whom she can share her distress, but she can be all this precisely because she is someone who lives in another language and in an elsewhere close enough for Jeanne to feel a connection, still far enough to enable her to give free reign to her imagination:

My dear partridge Phyllis, why am I writing to you in the Prairies, so far from me in Canada, perhaps it is because I do not know you at all and it is easier for me to talk, I cannot talk to my girlfriends à l'École Ste-Marguerite de Sherbrooke, neither to my mother or my older sister, they do not know me, I do not know these strangers, they do not see I am in danger, jeopardized perilously, I am choking on a fishbone at the table and nobody helps me, I am parched with thirst and my family is a desert, si je t'écrivais en français, tu ne comprendrais rien et eux ils connaîtraient tous mes secrets, oh Phyllis, chère amie, I know you understand me, my kindred soul, my unknown sister nevertheless, in spite of everything, in spite of my clumsiness, despite my awkwardness, even though you are in another part of the world, there is no distance, no language, no time between us (The Marriageable Daughter 15).

Accordingly, Phyllis' spatial reality remains firmly anchored in the recognizable otherness of the Western Canadian geography: "Phyllis, is your father one of those cowboys and capitalists who go after the bulls in the Prairies with a firm grasp around the beast's neck? Oh Sherbrooke, you know, is not a shining city rising from the sea! Making a mountain out of a molehill" (The Marriageable Daughter 29). ${ }^{1}$ This Albertan space is seen by Jeanne as being both different and

\footnotetext{
${ }^{1}$ Phyllis, ton père est-il un de ces cow-boys capitalistes de l'Alberta, courant après les taureaux dans les Prairies, empoignant fermement le lasso enroulé autour du cou de la
} 
connected, and the sense of connection is reinforced by Jeanne's frequent references to a shared Canadian North: "I see Great Slave Lake, Great Bear Lake in the Northwest Territories, Victoria Island full of cracks, Melville Island, and the marriageable daughter in an ice cube on Ellesmere Island, in the centre of the North Pole" (The Marriageable Daughter 41).

The cross-writing experience is not conditioned by the aesthetics of realism. Jeanne's unusual English receives a cursory justification in the plot structure by her declared status as a Francophone. However, the creative, lyrical dimension of the English text is clearly more related to her own romantic, poetic personality than to her linguistic background per se. At no time do I attempt to reconstruct how an imperfectly bilingual Québécois Francophone would actually speak (or write) in English. Nor do I use any of the forms of code-switching typical of communication in contexts of languages in contact, such as "tags," "loan blends" or "shifting word boundaries" (Hamers and Blanc 259-266). The rare insertion of sentences or expressions in French, as in the quotes above, is associated with the rhetorical functions of emphasis and local colour for a crosslinguistic reading. Consistent with the communicative aesthetics of writing towards difference within a shared space where solidarity and connection are possible (although not necessarily achieved), there is also no attempt, notwithstanding some undercurrents of French syntax, to arrive at an inbetween, hybrid space.

My Husband the Doctor is a sequel to The Marriageable Daughter. Jeanne is fascinated by the name Medicine Hat "what a wonderful name for a city, charming dream of a magician who let go out of his hat rabbits in the Prairies and also fantastic birds, and you are in that hat, that medicare hat, Phyllis" (The Marriageable Daughter 13). By the end of the book, however, the magician has become a repressive force, and Jeanne sees herself (and Phyllis) as living in a madhouse tormented by Doctor Hat:

Phyllis, my delft-blue elf, my infinite and eternal world of imagination [...] the demon Doctor Hat surrounded by his specialists and friends has the charge to drag us down by the hair and precipitate us into the Abyss [...] come Phyllis with your sword and trumpet of glory to kill the dragon with three heads while he strips me naked in my cell in the mental hospital and eats my thoughts (The Marriageable Daughter 66).

These images are the starting point for My Husband the Doctor. An anonymous woman narrator, patient in a psychiatric hospital, ostensibly writes her autobiography, addressing it as a letter to her Anglophone husband, chief psychiatrist of the hospital. The autobiography mutes into a "post-mortem

bête, oh Sherbrooke, tu sais, n'est pas une ville lumineuse s'élevant au-dessus de la mer, faisant d'une mouche un éléphant" (La fille à marier 51). 
examination on my husband" (My Husband the Doctor 68) but the narrator refuses to "write all the pages for my husband's biography, which document his troubles" (69). Numbered diary entries replace the letter form, but the dialogical dimension of the writing is maintained by the constant and explicit evocation of a recipient or narratee, first the narrator's husband, and then, increasingly, "ladies and gentlemen of the jury" (59), "dear Commissioners, Madam Chairman and Mister Minister" (p. 68), "dear Members of Parliament" (70). It is not clear whether the narrator has actually killed her husband, the psychiatrist, or simply imagined his death. In either case, her text is a plea of innocence. As in The Marriageable Daughter, the narrator's status as a Francophone writing to an Anglophone jury offers a surface justification for the linguistic shortcomings of her English prose. However, here too, the disjointed effect created by the use of the dictionary as an integral part of the writing process is more obviously read as an effect of the narrator's unstable mental processes, rather than her lack of linguistic competence.

\section{Self-translation and Cross-writing Aesthetics}

The notion of cross-writing is also useful in situating the relationship of each version to the other. The self-translating process does not attempt to provide a mirror image of the inter-linguistic dialogue. I have not tried to recreate the playful French of a somewhat bilingual young Anglophone adolescent writing to her Francophone pen pal, or to have an Anglophone psychiatrist write to his estranged Francophone wife. The basic structure of each text remains the same in translation. In other words, the cultural perspective of the narrative remains consistent with my own identity as a Francophone Québécois. This may have consequences for the critical reception of each book. Linguistically, Anglophone readers can identify directly with Phyllis and the Anglophone jury members as narratees, whereas Francophone readers, culturally, are linked to the narrator. However, in keeping with my cross-cultural communicative aesthetics, readers from both languages have access to the same call for solidarity to transcend the Anglophone-Francophone cross-cultural divide.

In contrast to what Hokenson and Munson call the bilingual text, where both versions acquire their meaning when brought together as one text, each language version of The Marriageable Daughter and My Husband the Doctor finds its own meaning as read in a particular cultural context at a specific historical time in Canada-Québec relations. The changes I have taken the liberty of making, as I move both texts into French, contribute to reinforcing a positive intercultural reading of the book in both contexts. Mindful of the differences between the two cultures, the direct political references of the English text are attenuated in French, particularly in Mon mari le docteur, so as to avoid a restrictively political, and probably negative reading of the book by Frenchspeaking Québécois, given their mounting dissatisfaction with the Canadian 
Confederation at the time (Gagnon, "Cross-writing..." 52-53). The English version narrator's declaration, "Letter to an English psychiatrist from your French-Canadian wife in your lunatic asylum" (My Husband 1), thus becomes, more neutrally, "Lettre au Docteur, de votre femme" (Mon mari 11). The psychiatrist identity as an Anglophone is presented implicitly, rather than explicitly: he is described as being born in "Pointe-Claire" (Mon mari 54) which only readers familiar with Québec could identify as a predominantly Anglophone suburb of Montréal.

However, consistent with the cross-cultural communicative approach, both French and English texts retain many of the metaphors I use to represent the rigid, stultified thinking that has so often dominated Canadian and Québécois conceptions of their cultural (and political) relationship within Canada. Both The Marriageable Daughter and La fille à marier include a revealing introductory quotation from Québec artist Paul-Emile Borduas: "Let us band together and shake the heavy slumber of Canadians" (The Marriageable Daughter 5). ${ }^{2}$ In the following passage from My Husband the Doctor and Mon mari le docteur, the relationship between Anglophones and Francophones is framed as unpropitious marriage bogged down in the unmoving confrontation between two historical monuments.

First the English text:

Doctor Hat did you really want this woman as your wife, to guard her in health and sickness, as long as she lives, as a good man should keep his wife? Did you really want to join her faithfully with your body? I am a chilled meat in a refrigerated wagon, but a consuming fire runs in my vain days and nights, our marriage is scheduled as an ancient monument, not a breath stirs the leaves, not a breath stirs the lake (My Husband 33).

The same images are kept in the French text:

Docteur, avez-vous vraiment voulu cette femme comme épouse afin de la garder malade ou en santé aussi longtemps qu'elle vivra, comme un honnête homme se doit de garder son épouse? Avez-vous vraiment voulu vous unir à elle fidèlement par votre corps? Je suis une viande froide dans un wagon réfrigéré, mais dans mes veines circule un feu dévorant jour et nuit, notre mariage est classé monument historique, pas un souffle ne fait trembler les feuilles, pas un souffle ne ride le lac (Mon mari 34).

The specific cross-cultural communicative function of the books within the shared Canadian Québécois space distinguish this experience in selftranslation from the post-colonial context of what Homi Babha calls the "split

2 "Puissions-nous, tous ensemble, troubler la lourde sieste canadienne" (La fille 9). 
space of enunciation" (The Location of Culture 38), or the global "translational culture" of migrants and mosaic subjects (38). Nor does Bhabha's hypothesis of an "international culture, based not on the exoticism of multiculturalism or the diversity of cultures, but on the inscription and articulation of culture's hybridity" (38) apply to my cross-writing experience. Within my own aesthetics, the more somber turn between The Marriageable Daughter and My Husband the Doctor, and the fact that the cross-writing experience stopped with the latter book, can be seen as a reflection of real difficulties within the cross-cultural communication process itself in the Canadian space. This finds an echo in the texts themselves, where neither Phyllis nor the Anglophone psychiatrist replies to the protagonist.

Given the cross-cultural communicative aesthetics of each book, it would be inappropriate to try to configure each, or both, as a double construction of the author's identity as a bilingual writing subject. If the intensity of Jeanne's revolt and that of the anonymous narrator of My Husband the Doctor certainly speak to a need for some emotional expression, with undercurrents of emotional trauma, this is not expressed directly, and neither book pretends to be in any way autobiographical, although an autobiographical intention is initially attributed to the anonymous narrator of My Husband the Doctor. This does not negate the fact that writing in English certainly offered me a fresh, creative start, and enabled me to address questions that I might not otherwise have tackled. English was not only devoid for me of the stylistic constraints of metropolitan French literary works, it was also free, in keeping with recent research into bilingual subjects (Harris et al. 257; Besemeres 34-35), of the painful affective undertones associated with the language of childhood experiences.

\section{The Cross-cultural Communicative Aesthetics and the Creative Process}

As a writer, moving into English was an integral part of the creative process, and self-translation part of the normal editing process, as one moves from a draft to the final text. This is demonstrated by the following passages from My Husband the Doctor and Mon mari le docteur:

I have my inky fingers and my thorns are my only delight in the Garden of Love, I write in the lonely cell, in vain, pensive, and full of painful desires, I mourn for my lost youth, what can do the little shield powdered with fleurs-delis? I don't feel equal to conform to discipline, the Doctor practices his French on me, I am not his rational grammar. If you'd like some new experiences, something beyond the limits of earthbound travelers, the lunatic asylum can expand your horizons, sweep you to a wide new spectrum of events and activities (My Husband 5-6). 
J'ai les doigts tachés d'encre et mes épines sont mes seuls délices au jardin d'Amour, j'écris dans la cellule solitaire, en vain, pensive et pleine de désirs douloureux, je pleure ma jeunesse perdue, que peut faire le petit écu semé de fleurs de lis? Je ne me sens pas le courage de me plier à la discipline, si vous aimez tenter de nouvelles expériences, quelque chose au-delà des limites des voyageurs terre-à-terre, l'asile d'aliénés peut élargir vos horizons, vous entraîner dans une vaste gamme d'événements et d'activités (Mon mari 13).

While this translation editing process serves to tighten up the French text, it also brought me back to French aesthetic norms. In the same way, the revisions to The Marriageable Daughter, carried out under the supervision of fiction writer Leon Rooke, can be seen to be guided by the need to bring the English text into some minimal compliance with Anglophone aesthetic and grammatical expectations (See Gagnon, "Cross-writing..." 53-54). In the self-translation process, this heightened awareness of French literary norms made it more difficult for me to replicate completely the disjointed, ungrammatical effect of the English texts, as the following passages from The Marriageable Daughter and La fille à marier illustrate:

I am alone, alone as the north Pole, are you alone in Medicine Hat, what a wonderful name for a city, charming dream of a magician who let go out of his hat rabbits in the Prairies and also fantastic birds, and you are in that hat, that medicare hat, Phyllis, what could happen to you in so nice company here in Sherbrooke, rivers whet their whistle, nothing ventured nothing gained, so they take the plunge, jump and vault with coated tongue... (The Marriageable 13)

Je suis seule, seulement aussi seule que le pôle Nord, es-tu seule, toi Phyllis, à Medicine Hat, quel beau nom pour une ville, rêve charmant d'un magicien qui laisse s'enfuir hors de son chapeau des lapins dans les Prairies et aussi des oiseaux fantastiques, et tu es dans ce chapeau, ce chapeau médicamenteux, Phyllis, rien ne saurait te manquer en si belle compagnie, ici à Sherbrooke, les rivières s'humectent le gosier, qui ne risque rien ne gagne rien, alors elles se jettent à l'eau (La fille 21).

These aesthetic and linguistic issues help shape the translation, alleviating the agrammatical dimension of the writing, but they do not constitute a rewriting of the original per se, such as one finds in Beckett's work (Oustinoff 13). The French translations remain faithful to the English text and even much of the disjointed, unusual writing style of the original, while rendered grammatical, was nonetheless maintained in French. Stylistically, the unusual English of both originals echoes Deleuze's position on the literary importance of strangeness: "Fine books are written in a sort of foreign language" (in Hokenson and Munson 167). This strangeness was tempered in French, but each book and its translation evoke a similar type of creative work on language. Petre Solomon, Paul Celan's Romanian translator, has observed that it was his decision to write some poetry 
directly in Romanian that subsequently enabled Celan to adopt a freer writing style in German (in Mysjkin102). Similarly, the move into English would continue to have considerable impact on my ensuing writing in French. My cross-writing experience would both speak to intercultural issues in Canada and nourish my writing style.

\section{Works cited}

Bhabha, Homi. The Location of Culture.London/New York: Routledge, 1994. Print.

Besemeres, Mary. "Language and Emotional Experience: The Voice of the Translingual Memoir." Bilingual Minds. Emotional experience, Expression and Representation. Ed.Aneta Pavlenko.34-58. Cleveland/Buffalo/Toronto: Multilingual Matters, 2006. Print.

De Paula, Lilian."The bilingual novel and the voice of a self-translator."La traduction des voixintra-textuelles/Intratextual Voices in Translation. Eds. Kirstiina Taivalkoski-Shilov and Myriam Suchet.185-204.Montréal: Éditions québécoises de l'oeuvre, collection VitaTraductiva, 2013. Print.

Gagnon, Daniel. My Husband the Doctor.Unpublished manuscript, 1984. Print.

Gagnon, Daniel. La Fille à marier. Montréal: Leméac. Prix Molson de l'Académie française, 1985. Print.

Gagnon, Daniel. Mon mari le docteur. Montréal: Leméac, 1986. Print.

Gagnon, Daniel. The Marriageable Daughter. Toronto: Coach House Press, 1989. Print.

Gagnon, Daniel. "Bilingual translation/writing in the Canada/Québec context." Sociocultural Approaches to Translation and Interpreting. Eds. Anthony Pym, Zuzana Jettmarová and Miriam Schlesinger. 121-130. Amsterdam/Philadelphia: John Benjamins, 2006. Print.

Gagnon, Daniel. "Cross-writing and Self-translating: One Canadian/Québec Experience."L'identité de la traduction et la traduction de l'identité. Eds. Madelena Gonzalez andFrancine Tolron. 46-59. Newcastle-upon-Tyne: Cambridge Scholars Press, 2006. Print.

Gagnon, Daniel. "Les mots du Docteur Hat." Traduction et enjeux identitaires dans le contextedes Amériques. Ed. Louis Jolicoeur. 165-175. Québec: Presses de l'Université Laval, 2007. Print.

Hamers, Josiane F. and Michale H. A. Blanc. Bilinguality and Bilingualism. Cambridge:Cambridge University Press (Second edition), 2000. Print.

Harris, Catherine L., Jean Berko Gleason and Ayşe Ayçiçeği."When is a First Language More Emotional? Psychophysiological Evidence from Bilingual Speakers."Bilingual Minds.Emotional experience, Expression and Representation.Ed. Aneta Pavlenko.257-283. Cleveland/Buffalo/Toronto: Multilingual Matters Ltd, 2006. Print.

Hokenson, Jan Walsh, and Marcella Munson.The Bilingual Text. History and Theory of LiterarySelf-translation. Manchester/Kinderhook: St. Jerome Publishing, 2007. Print.

Munday, Jeremy (2001). Introducing Translation Studies. Theories and Applications.London/New York: Routledge. Print.

Mysjkin, Jan H. "Présentation." Paul Célan Poèmes Roumains, La Nouvelle Revue Française.578 (2006) : 100-102. Print. 
Nikolaou, Paschalis and Marie-Venetia Kyritisi.Translating selves: experience and identity between languages and literatures.Foreword by Mona Baker.London/New York: Continuum, 2008. Print.

Oustinoff, Michaël. Bilinguisme d'écriture et auto-traduction. Julian Green, Samuel Beckett,Vladimir Nabokov. Paris: L'Harmattan, 2001. Print.

Pavlenko, Aneta. "Bilingual Selves."Bilingual Minds. Emotional experience, Expression and Representation.Ed. Aneta Pavlenko.1-33. Cleveland/Buffalo/Toronto: Multilingual Matters, 2006. Print.

Wilson, Rita. "The Writer's Double: Translation, Writing, and Autobiography." Romance Studies 27. 3(2009): 186-198. Print. 